\title{
Distribution and Environmental Significance of Phosphorus Forms in Riparian Soils and River Sediments of Jianxi Basin, Fujian Province
}

\author{
Hongmeng Ye ${ }^{1-3}$, Xuyin Yuan ${ }^{1 *}$, Rui Zhou ${ }^{1}$, Jie Wan ${ }^{1}$, Jian Xu' \\ ${ }^{1}$ Key Laboratory for Integrated Regulation and Resources Development on Shallow Lakes, Ministry of Education, \\ College of the Environment, Hohai University, Nanjing, Jiangsu 210098, P.R. China \\ ${ }^{2}$ College of Ecology and Resource Engineering, Wuyi University, Wuyishan, Fujian 354300, P.R. China \\ ${ }^{3}$ Fujian Key Laboratory of Eco-Industrial Green Technology, Wuyishan, Fujian 354300, P.R. China
}

Received: 20 January 2017

Accepted: 29 March 2017

\begin{abstract}
Phosphorus as a major nutrient element in water ecosystems is a key factor affecting algae growth in rivers. This paper adopts the sequential extraction method for phosphorus fractionation to study the distribution of phosphorus forms in riparian soils and peripheral river sediments, then to analyze the relationship between different phosphorus forms and their significance within a watershed environment. The results show that: 1) the contents of $\mathrm{NH}_{4} \mathrm{Cl}-\mathrm{P}, \mathrm{BD}-\mathrm{P}$, and $\mathrm{HCl}-\mathrm{P}$ in riparian soils are more widespread than those in river sediments, 2) the distribution patterns of phosphorus fractions in different catchments of Jianxi Basin are varied for soil and sediment, and 3) the ratio of BAP/TP is the highest in Chongyangxi catchment and the lowest in Songxi catchment. Phosphorus in riparian soils is mainly affected by agricultural activities, significantly for $\mathrm{NaOH}-\mathrm{P}$ and $\mathrm{HCl}-\mathrm{P}$. And phosphorus forms in sediments are obviously affected by domestic sewage. The phosphorus contents and fractions in riparian soils change more significantly than those in river sediments.
\end{abstract}

Keywords: phosphorus, chemical speciation, riparian soil, sediment, Jianxi Basin

\section{Introduction}

Phosphorus is one of the main essential nutrients for biological growth and biogeochemical cycles and plays an important role in terrestrial and aquatic ecosystems [1-2]. In aquatic ecosystems, phosphorus has been identified as a key factor controlling algal growth in rivers or lakes as excessive phosphorus input caused

*e-mail: yxy_hjy@hhu.edu.cn by human activities can lead to eutrophication that may pose a serious health hazard to humans [3-4]. Phosphorus exists in a variety of complex chemical forms, and not all the forms of $\mathrm{P}$ are likely to be released from particulate and thereby increase eutrophication [5-6]. Its morphology and content are also affected by a variety of factors, and may be subject to variations in response to the evolution of physical, chemical, and biological conditions. The form of phosphorus determines its migration, transformation and bioavailability in the environment [7-8], and different forms of phosphorus make different contributions to the eutrophic water. 
Accordingly, the understanding of the distributions and bioavailability of phosphorus forms in an aquatic ecosystem is the key to evaluating water quality and assessing their influence on eutrophication [9-10].

The riparian zone as the transitional zone between terrestrial and aquatic communities is a natural protective barrier for rivers and wetlands, and is an important component and health indicator of the river and wetland ecosystem. The functions of water conservation, bank stability, erosion control, flood storage, and drought management, as well as the maintenance of biodiversity, ecological balance, and ecological tourism are very important due to the spatial structure and the unique habitat conditions of the riparian zone [11-12]. Besides seasonal fluctuations, the influence of grazing, farming, leisure, entertainment, and other human activities may also induce major disturbance to the river water, which may in turn cause phosphorus accumulation in the riparian soil due to the special location of the riparian zone. Driven by the surface runoff flowing into rivers, riparian soil could be continuously carried into streams and become the main source of river sediment [13-14]. Therefore, the riparian zone as a phosphorus library plays a dual role of phosphorus sink and source, and serves as a leading factor for phosphorus accumulation in river sediment. Different forms of phosphorus in soil and sediment have different bioavailabilities and environmental geochemical behaviors $[8-10,15]$. The phosphorus content and form distribution contain biogeochemical information, which is of major significance for us for studying the phosphorus content and form distribution in riparian soils and river sediments.

At present, many domestic and international scholars have done a lot of research concerning the distribution of phosphorus fractions in sediments [16-17]. But most of them are focused on relatively broad water such as lakes, reservoirs, and gulfs under eutrophication state, and relatively insufficient study has been dedicated to river basins [13]. Compared to that of sediment, the distribution of phosphorus fractions in riparian soil is less studied. In particular, the study concerning influence of phosphorus accumulation in the riparian soil on the river sediments has rarely been conducted $[2,18]$.

Jianxi Basin is in an oligotrophic to mesotrophic state located in Fujian province, and there is no report about the spatial distribution of total phosphorus and phosphorus fractions in the riparian soils and river sediments in Jianxi Basin. But those are very important for a better understanding of the content and bioavailability of phosphorus from Jianxi Basin. Its phosphorus state is a key for trophic state transition and helpful for providing an ecosystem service to downstream waters. It is also of prime importance in the framework of water management and restoration of water bodies, and the riparian ecological remediation. This paper adopts the separation method for phosphorus fractionation to study the distribution of phosphorus forms in riparian soils, which is then compared with the corresponding phosphorus forms distribution in the surface sediments from Jianxi Basin.
In order to better understand the geochemical behavior of phosphorus and its bioavailability in watershed soils and sediments, the objectives of the present study were: 1) to identify the major phosphorus fractions in riparian soils and in surface sediments, 2) to evaluate the bioavailability of soil or sediment phosphorus and analyze the environmental characteristics in different river reaches, and 3) to analyze the relationships of phosphorus fractionation distribution in riparian soils and river sediments, along with their significance to the watershed environment.

\section{Material and Methods}

\section{Study Area}

The Jianxi is one of the three largest tributaries tied to the upper reaches of the Minjiang River, which is the largest river in southern China's Fujian Province. It originated from Xianxia Ridge of Wuyi Mountain and is derived from three major water courses, e.g., the Chongyangxi, Nanpuxi, and Songxi rivers, which cover a total area of $16,396 \mathrm{~km}^{2}$ and account for about $27 \%$ of the total area of Minjiang Basin. It has a total length of $294 \mathrm{~km}$, an average annual runoff of 15.59 billion $\mathrm{m}^{3}$, an average annual sediment load amount of 1.58 million tons, and an average river gradient of $0.8 \%$ [19]. It flows through seven counties, namely (from north to south) Wuyishan, Jianyang, Pucheng, Songxi, Jian'ou, and Nanping. According to the administrative division, Jianxi Basin belongs to Nanping City, which includes six counties and a total of 66 villages and towns. Specifically, the six counties are Wuyishan, Jianyang, Pucheng, Songxi, Zhenghe, and Jian'ou, which consist of 7, 11, 17, 8,9 , and 14 towns, respectively. Among the three major water sources, the Chongyangxi flows through Wuyishan, Jianyang, and Jian'ou counties, being home to the most developed tourism with the highest tea garden coverage and catering industry; the Nanpuxi flows through Pucheng and Jianyang with more industries and vegetable fields distributed along its coast; the Songxi flows through Songxi, Zhenghe, and Jian'ou with a relatively small population, the largest forest land area, and developed crop farming [20-21]. Those three major rivers finally merge into the Jianxi River in the Jian'ou.

Jianxi Basin is a subtropical monsoon climate zone, with an average annual rainfall of 1,600 2,000 $\mathrm{mm}$. The rainfall may exceed $2,700 \mathrm{~mm}$ locally. Annually there are 164 177 days with precipitation. According to factors dictating the weather, it can be divided into four periods, e.g., spring rains (March to April), mould rains (May to June), typhoons and thunderstorms (July to September), and the dry season (October to February) [19]. According to the 2015 Urban Statistical Yearbook of Nanping County, the basin had a population of 1.573 million, corresponding to a population density of about $95 / \mathrm{km}^{2}$ [21]. In the past decade, the total outflux of the river basin has been growing steadily, coupled by a transition from 
the traditional agriculture dominated by crop farming to a combination of agriculture, forestry, animal husbandry, and fisheries [22]. The proportion of the tertiary industry in the industrial structure has increased year by year with a rapid development of tourism in Jianxi Basin. However, the per capita GDP is 47,268 yuan/year, being slightly lower than that of Fujian Province [21]. Affected by many pollution factors, the basin water quality has degraded from the original oligotrophic state to a mesotrophic state, with the change accelerating year by year [21]. The land types used in the basin are comprehensive, being mainly forest land and cultivated land, followed by urban land and other soil types [20-21]. The types of soil are mainly red soil, yellow soil, and paddy soil formed by sandy rock and granite [21-22].

\section{Sample Collection and Treatment}

During the early stage of sampling, the water supply and drainage system of the village is investigated, taking into consideration the river outfall, coastal villages, and enterprise distribution in Jianxi Basin. During September 2016 (typhoon and thunderstorm season), we set up 23 sampling points to collect samples from both river sediments and riparian soils, whose distribution is shown in Fig. 1. Among them, the sampling points numbered 1 to 6 are located on the Chongyangxi River, 7 to 12 are on the Nanpuxi River, 13 to 18 are on the Songxi river, and 19 to 23 are on the Jianxi River.

Each river sediment sample is formed by mixing five collections randomly acquired from an area within $10 \mathrm{~m}$ from river shoreline at depths randomly set at $0 \sim 10 \mathrm{~cm}$. A total of 23 sediment samples were collected. Likewise, each riparian soil sample is formed by mixing multiple collections randomly acquired from an area within $20 \mathrm{~m}$ (the fluctuation of water level could affect this number) from river shoreline at depths randomly set at $0 \sim 10 \mathrm{~cm}$ following an S-shaped distribution. A total of 23 riparian soil samples were collected. The collected samples were filtered to remove the plant residues and stones, and subsequently put into sealed polyethylene bags tagged with registration numbers. Those bags were then brought back to the laboratory, where the collected samples were naturally desiccated, crushed, ground, and filtered through a 100-mesh nylon sieve.

\section{Measurement and Analysis of Samples}

Sediment and soil samples are analyzed with total nitrogen $(\mathrm{TN})$ measured using the concentrated $\mathrm{H}_{2} \mathrm{SO}_{4}$ digestion method [23] and the TP determined by the molybdate colorimetric method with perchloric acid digestion [24]. $\mathrm{pH}$ was measured with a glass electrode in a slurry of $10 \mathrm{~g}$ of soil and $25 \mathrm{~cm}^{3}$ of deionized water [23]. The organic matter $(\mathrm{OM})$ in the sediments is measured after treatment with $\mathrm{K}_{2} \mathrm{Cr}_{2} \mathrm{O}_{7} / \mathrm{H}_{2} \mathrm{SO}_{4}$ according to the Walkey-Black method [25]. The size distribution of sediments, including clay $(0-4 \mu \mathrm{m})$, silt $(4-63 \mu \mathrm{m})$, and sand fractions $(63-500 \mu \mathrm{m})$ is determined by a laser particle size analyzer [26].

A sequential extraction method [27] is used to obtain the geochemical P fractions [28]. The phosphorus present in the samples is divided into loosely adsorbed phosphorus that can be extracted with $1.0 \mathrm{M} \mathrm{NH}_{4} \mathrm{Cl}$ (referred to as $\mathrm{NH}_{4} \mathrm{Cl}-\mathrm{P}$ ). The reductant phosphorus is extracted using $0.11 \mathrm{M} \mathrm{Na}_{2} \mathrm{~S}_{2} \mathrm{O}_{4} / \mathrm{NaHCO}_{3}$ (BD-P). The phosphorus bound to metal oxides is extracted with $1.0 \mathrm{M}$ sodium hydroxide (NaOH-P). The calcium-bound phosphorus is released by $0.5 \mathrm{M} \mathrm{HCl}$ hydrochloric acid (HCl-P) [28]. Each extraction step is performed at room temperature in an orbital shaker running at 4,500 r/min for $2 \mathrm{~h}$. Each $100 \mathrm{ml}$ centrifuge tube takes $0.50 \mathrm{~g}$ dried sediment sample along with $25 \mathrm{~mL}$

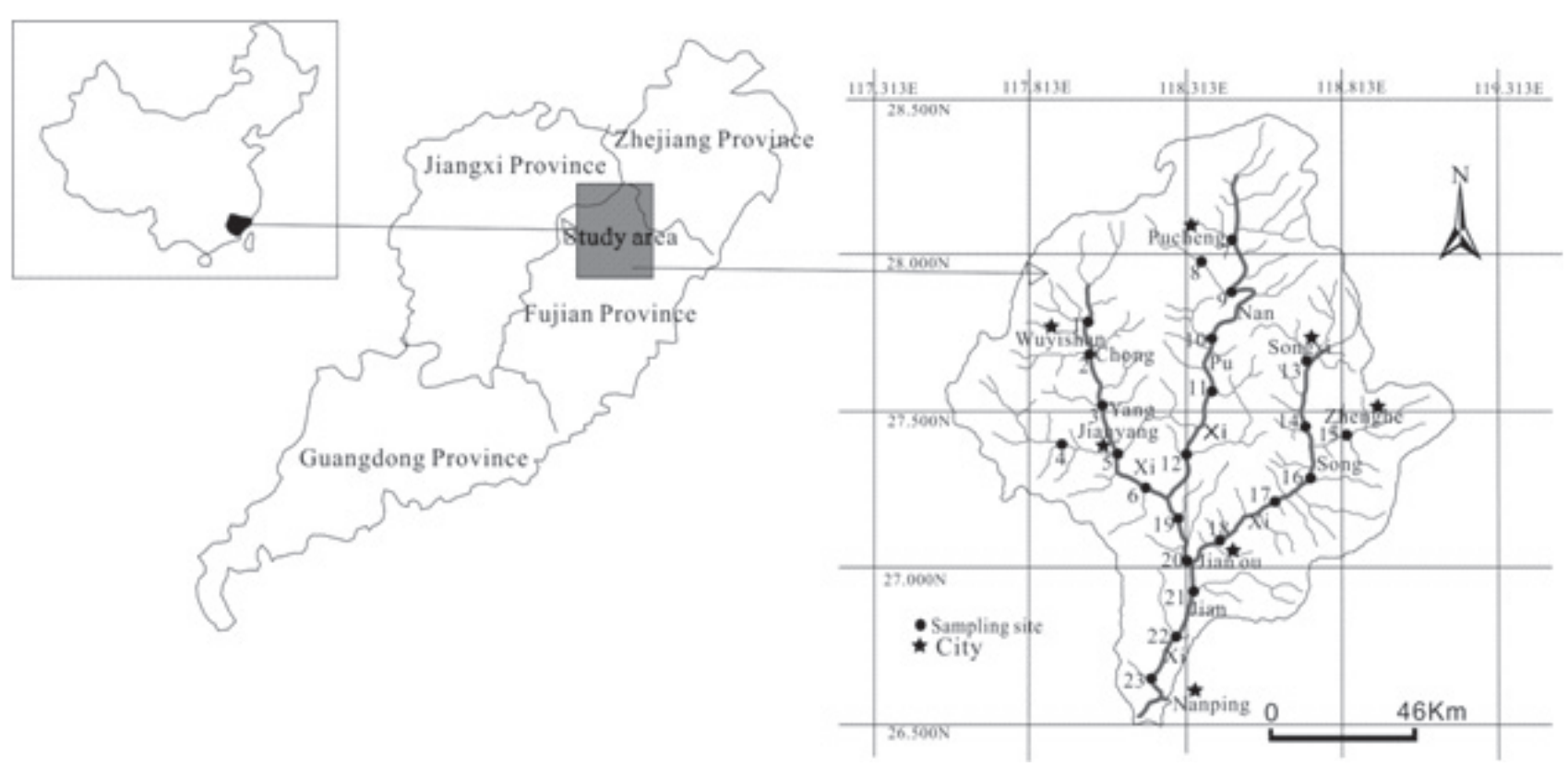

Fig. 1. Map of Jianxi watershed with sampling sites. 
solute. The extracts are centrifuged for $10 \mathrm{~min}$ at 4,500 r/ min and the supernatants are filtered through a $0.45 \mu \mathrm{m}$ $\mathrm{GF} / \mathrm{C}$ filter membrane. Each $\mathrm{P}$ fraction is quantitatively assessed by the molybdenum blue/ascorbic acid method [29]. The sum of $\mathrm{NH}_{4} \mathrm{Cl}-\mathrm{P}, \mathrm{BD}-\mathrm{P}, \mathrm{NaOH}-\mathrm{P}$, and HCl-P is regarded as IP, while the bio-available $\mathrm{P}$ (BAP) is calculated by the addition of $\mathrm{NH}_{4} \mathrm{Cl}-\mathrm{P}, \mathrm{BD}-\mathrm{P}$, and $\mathrm{NaOH}-\mathrm{P}$

\section{Statistical Analyses}

This study analyzed the whole samples in triplicate to ensure the precision of the results reported as the average values. Pearson correlation coefficients were employed for better understanding of the relationships among soil phosphorus forms and sediment phosphorus forms. The descriptive statistical analysis and correlation concerning the physical indicators of soil and sediments are conducted using SPSS20.0 statistical software, while charts are plotted using Origin 9.0 software. Differences in soil and sediment total concentration and phosphorus sequential fractions among all the sample sites were considered as significant if $\mathrm{p}<0.05$.

\section{Results and Discussion}

\section{Basic Physicochemical Characteristics of Riparian Soils and River Sediments}

According to Table 1, there is a certain difference concerning the nutrient element contents in riparian soils and river sediments. The average contents of OM, TN, and TP in the riparian soil are $7.33 \%, 2,420.80 \mathrm{mg} / \mathrm{kg}$, and $786.85 \mathrm{mg} / \mathrm{kg}$, respectively. The average contents of $\mathrm{OM}, \mathrm{TN}$, and TP in the river sediments are $6.95 \%$, $1858.05 \mathrm{mg} / \mathrm{kg}$, and $624.68 \mathrm{mg} / \mathrm{kg}$, respectively. It should be noted that the TP level in the sediment was a little more than the critical level of $0.6 \mathrm{mg} / \mathrm{g}$ for polluted sediments as described by Katsaounos et al., which indicated that the studied river was to a certain extent disturbed by human activities and contaminated [30]. Obviously, the contents of OM, TN, and TP in the riparian soils are higher than those in the sediments. The related report showed that urbanization affected nutrient balance in topsoil [22]. This reflects that nutrients are more abundant in riparian soils due to the greater accumulation of nutrients driven by land and shore anthropogenic activities [12, 18]. Besides, it also highlights that the riparian zone, as the last barrier preventing rainfall runoff from entering the river, can significantly reduce the migration of nutrient elements from land surface water and underground water into the aquatic ecosystem, reduce the direct impact of the pollutant input from land system on the aquatic ecosystem, and protect river water quality. Previous studies have shown that the removal of nitrogen and phosphorus in surface runoff and groundwater in the riparian zone is one of the main factors for reducing non-point pollution load [14, 31]. For example, research by Mankin [32] shows that the removal efficiency of TN and TP exceeds $85 \%$ in the riparian buffer zone.

As for phosphorus forms, the average contents of $\mathrm{NH}_{4} \mathrm{Cl}-\mathrm{P}, \mathrm{BD}-\mathrm{P}, \mathrm{NaOH}-\mathrm{P}$, and $\mathrm{HCl}-\mathrm{P}$ in riparian soils are $6.83 \mathrm{mg} / \mathrm{kg}, 69.79 \mathrm{mg} / \mathrm{kg}, 144.17 \mathrm{mg} / \mathrm{kg}$, and $116.11 \mathrm{mg} / \mathrm{kg}$, respectively. Their average contents in river sediments are $1.79 \mathrm{mg} / \mathrm{kg}, 36.50 \mathrm{mg} / \mathrm{kg}, 225.75 \mathrm{mg} / \mathrm{kg}$, and $104.30 \mathrm{mg} / \mathrm{kg}$, respectively. Obviously, the average phosphorus forms in riparian soils and sediments follow the order: $\mathrm{NaOH}-\mathrm{P}>\mathrm{HCl}-\mathrm{P}>\mathrm{BD}-\mathrm{P}>\mathrm{NHCl}_{4}-\mathrm{P}$. Comparing the different forms of phosphorus, the contents of $\mathrm{NH}_{4} \mathrm{Cl}-\mathrm{P}$ and BD-P in riparian soils are much higher than those in sediments, with the former being slightly higher than the latter for HCl-P, and the former being lower than the latter for $\mathrm{NaOH}-\mathrm{P}$. These differences are related to various factors such as acidity, conductivity, redox potential, particle size composition, bacterial activity, pollution source, and other relevant environmental factors related to soil and sediments [14, 33-35]. For example, soil pH and clay content are reported to have a strong relationship with the P sorption capacity of soils, as they are related to the

Table 1. Distribution of nutrient elements and phosphorus fractions in riparian soils and river sediments.

\begin{tabular}{|c|c|c|c|c|c|c|c|c|c|c|c|c|}
\hline \multirow{2}{*}{ Item } & Ave. & Min. & Max. & SD & CV (\%) & Ave. & Min. & Max. & SD & CV (\%) \\
\cline { 2 - 12 } & \multicolumn{9}{|c|}{ Soil } & \multicolumn{5}{|c|}{ Sediment } \\
\hline $\mathrm{pH}$ & 5.58 & 4.66 & 6.05 & 0.36 & 6.51 & 5.39 & 4.50 & 6.30 & 0.49 & 9.15 \\
\hline $\mathrm{OM}(\%)$ & 7.33 & 5.01 & 13.21 & 2.09 & 28.48 & 6.95 & 4.46 & 13.09 & 2.07 & 34.09 \\
\hline $\mathrm{TN}(\mathrm{mg} / \mathrm{kg})$ & $2,420.80$ & $1,344.19$ & $3,172.36$ & 403.97 & 16.69 & $1,858.05$ & $1,268.70$ & $2,421.17$ & 365.75 & 19.68 \\
\hline $\mathrm{TP}(\mathrm{mg} / \mathrm{kg})$ & 786.85 & 343.61 & $1,095.63$ & 232.20 & 36.46 & 624.68 & 264.01 & $1,045.40$ & 201.61 & 32.27 \\
\hline $\mathrm{NH}_{4} \mathrm{Cl}-\mathrm{P}(\mathrm{mg} / \mathrm{kg})$ & 6.83 & 5.16 & 14.28 & 1.88 & 27.54 & 1.79 & 0.56 & 3.48 & 0.84 & 49.48 \\
\hline $\mathrm{BD}-\mathrm{P}(\mathrm{mg} / \mathrm{kg})$ & 69.79 & 36.87 & 99.95 & 17.70 & 25.36 & 36.50 & 22.53 & 49.89 & 6.55 & 30.78 \\
\hline $\mathrm{NaOH}-\mathrm{P}(\mathrm{mg} / \mathrm{kg})$ & 144.17 & 75.98 & 303.25 & 54.54 & 37.83 & 225.75 & 87.72 & 406.11 & 90.40 & 14.14 \\
\hline $\mathrm{HCl}-\mathrm{P}(\mathrm{mg} / \mathrm{kg})$ & 116.11 & 45.10 & 248.65 & 60.78 & 52.35 & 104.30 & 50.81 & 172.93 & 28.65 & 21.35 \\
\hline $\mathrm{Clay}(\%)$ & 7.95 & 4.01 & 10.90 & 3.29 & 41.38 & 4.36 & 3.76 & 8.59 & 1.95 & 44.72 \\
\hline Silt $(\%)$ & 71.05 & 68.33 & 73.63 & 21.89 & 30.81 & 64.50 & 58.94 & 80.55 & 25.44 & 39.44 \\
\hline Sand $(\%)$ & 21.17 & 10.55 & 27.71 & 5.66 & 26.74 & 31.18 & 14.56 & 37.42 & 12.09 & 38.77 \\
\hline
\end{tabular}


amounts of $\mathrm{Al}, \mathrm{Fe}$, and $\mathrm{Ca}$ present in the soil solution [36]. Both the riparian soil and river sediments are acid because Jianxi Basin belongs to a granite area of southeastern China. But there are differences in material composition between the riparian soil and the river sediments [17]. The particle size of riparian soil is smaller than that of river sediments in the investigated area. Clay and silt ratio in riparian soil should be greater than that in river sediments, and the latter is dominated by silt and sand (Table 1).

\section{Comparison of Different Phosphorus Forms in Riparian Soils and River Sediments}

In order to further study the characteristics of the phosphorus fractions, we plot the proportion of phosphorus fraction contents and relative contribution values associated with different phosphorus forms in riparian soils and river sediments (Fig. 2). It can be seen from the graph that the distribution of phosphorus forms differs from site to site, and the trend of phosphorus composition variation is not completely consistent between river sediments and riparian zone soils. For example, the inorganic phosphorus content (the sum of the total phosphorus form content) peaks $(634.74 \mathrm{mg} /$ $\mathrm{kg}$ ) at site 16 with riparian soil, which is located at the midstream of Songxi. The inorganic phosphorus in the river sediment peaks at site 18 of Songxi, reaching 557.09 $\mathrm{mg} / \mathrm{kg}$. Generally speaking, the pollutants present in the sediments are not only from the nearby riparian soils, but are also derived from the upstream non-point and point pollution sources. The particles with smaller sizes can be transported farther from land into the water [17].

The fraction ranking of four phosphorus forms in riparian soils differs from sampling point to sampling point. The ranking of $\mathrm{P}$ fraction content and relative contribution at 5, 11, and 19 sampling sites follows the order of $\mathrm{NaOH}-\mathrm{P}>\mathrm{BD}-\mathrm{P}>\mathrm{HCl}-\mathrm{P}>\mathrm{NH}_{4} \mathrm{Cl}-\mathrm{P}$; the ranking at $7,14,17,18$, and 21 sampling sites follows the order of $\mathrm{HCl}-\mathrm{P}>\mathrm{NaOH}-\mathrm{P}>\mathrm{BD}-\mathrm{P}>\mathrm{NH}_{4} \mathrm{Cl}-\mathrm{P}$; the ranking at the other sample points follows the order of $\mathrm{NaOH}-\mathrm{P}>$ $\mathrm{HCl}-\mathrm{P}>\mathrm{BD}-\mathrm{P}>\mathrm{NH}_{4} \mathrm{Cl}-\mathrm{P}$. This is likely due to the various extents to which the different geographical locations and land types in the riparian soil are developed [14]. The variation of phosphorus content in the soil samples at each riparian zone is mainly induced by local anthropogenic activities [22].

By contrast, the ranking of four phosphorus forms in sediments follows an unchanged pattern, e.g., $\mathrm{NaOH}-\mathrm{P}>$ $\mathrm{HCl}-\mathrm{P}>\mathrm{BD}-\mathrm{P}>\mathrm{NH}_{4} \mathrm{Cl}-\mathrm{P}$ at all sampling points. Also, the content of $\mathrm{NaOH}-\mathrm{P}$ exceeds those of other three forms by a big margin, accounting for $59.65 \%$ of IP on average. The relative ratios of $\mathrm{HCl}-\mathrm{P}, \mathrm{BD}-\mathrm{P}$, and $\mathrm{NH}_{4} \mathrm{Cl}-\mathrm{P}$ to IP are $29.13 \%, 10.70 \%$, and $0.52 \%$, respectively. It is visible that $\mathrm{NaOH}-\mathrm{P}$ is the main form of IP in Jianxi sediment. This phenomenon is in agreement with the previous reports about most of lakes or rivers in southern China, but is different from Lake Dalinouer in northwestern China, whose HCl-P is the main form [37]. In alkaline soils, P will primarily bind to $\mathrm{Ca}$; in weathered acidic soils, $\mathrm{P}$ will primarily bind to $\mathrm{Al}$ and $\mathrm{Fe}$ hydroxides [36]. This would be the main reason why the sediment from Jianxi Basin had less phosphorus bound to $\mathrm{Ca}$ and more phosphorus bound to $\mathrm{Fe} / \mathrm{Al}$.
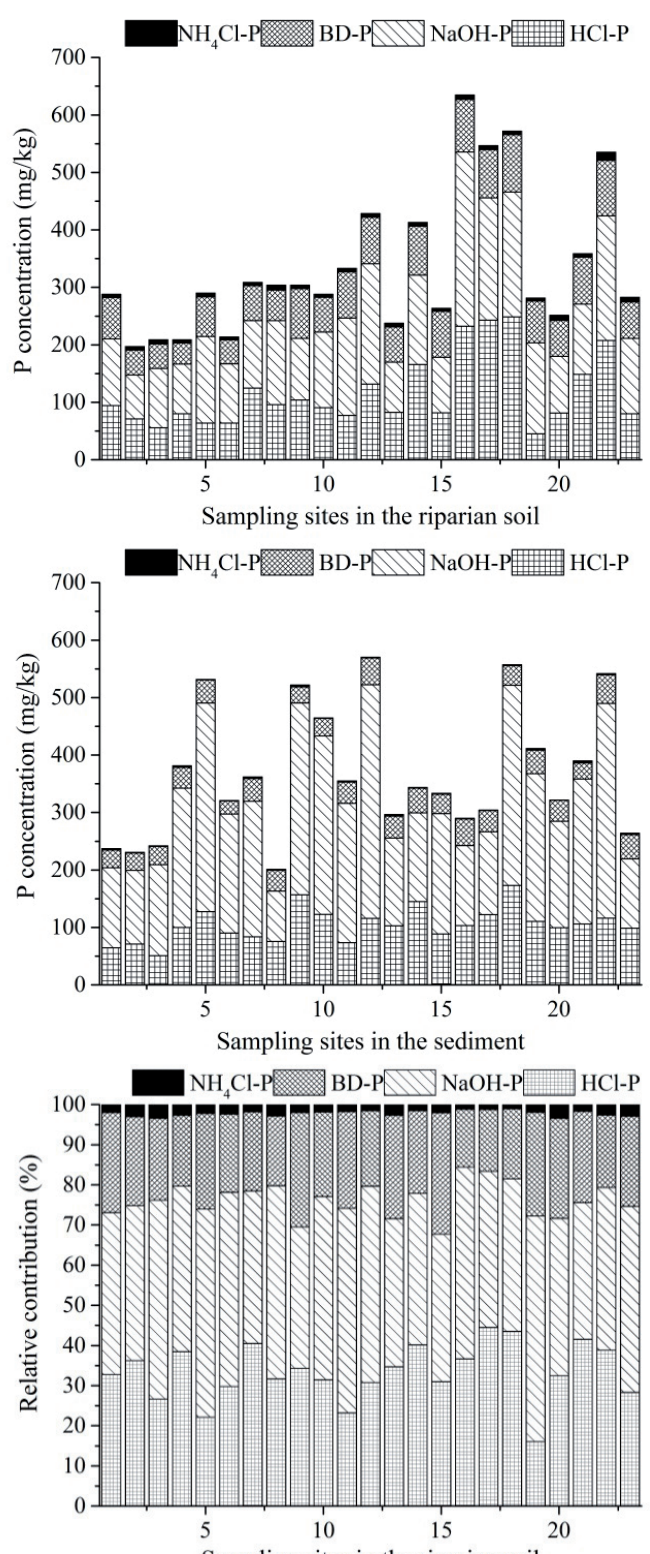

Sampling sites in the riparian soil

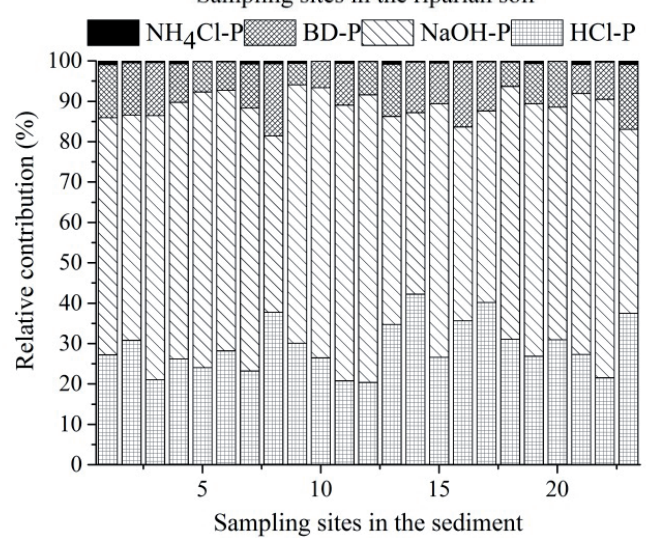

Fig. 2. Relative contributions of $\mathrm{P}$ fractions in riparian soils and river sediments in all samples. 
In order to further study the distribution characteristics of phosphorus forms and reveal the environmental significance, the distribution of phosphorus fraction content and composition in different sub-catchments
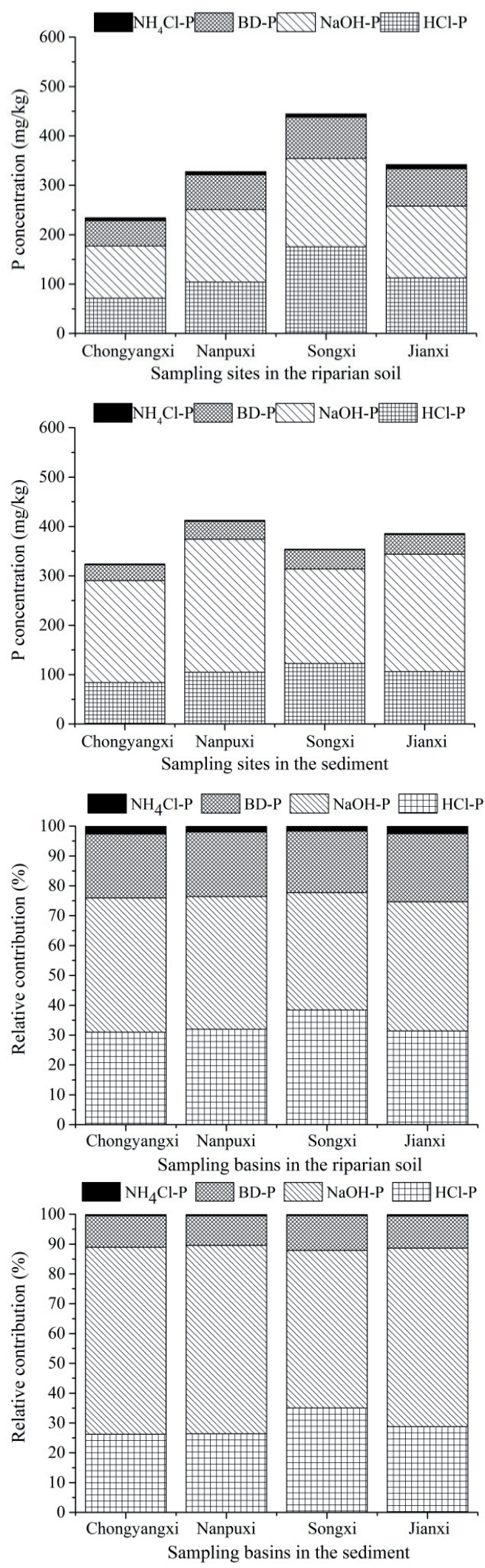

Fig. 3. Relative contributions of $\mathrm{P}$ fractions in riparian soils and river sediments at different rivers. or river reaches are plotted in Fig. 3. The individual distribution characteristics of four phosphorus forms are discussed below.

\section{Distribution Characteristics of Loosely Adsorbed Phosphorus $\left(\mathrm{NH}_{4} \mathrm{Cl}-\mathrm{P}\right)$}

The concentrations of $\mathrm{NH}_{4} \mathrm{Cl}-\mathrm{P}$ representing the loosely adsorbed $\mathrm{P}$ may include the dissolved $\mathrm{P}$ in pore water [38].

As Fig. 3 shows, the content of $\mathrm{NH}_{4} \mathrm{Cl}-\mathrm{P}$ and the ratio of total $\mathrm{NH}_{4} \mathrm{Cl}-\mathrm{P}$ to total phosphorus in river sediments are much lower than those in riparian soils in all river reaches of the investigated area. This could be partially related to the finer particle size of the riparian soil. Previous studies have shown that finer soil particles lead to higher $\mathrm{NH}_{4} \mathrm{Cl}-\mathrm{P}$ content and more conducive $\mathrm{NH}_{4} \mathrm{Cl}-\mathrm{P}$ adsorption [13]. In addition, the observed pattern can also be partially caused by the fact that the riverbank of the investigated area is dominated by natural slopes, the stream is of the mountainous river type, and the distribution of the plants on both sides of the river is abundant [20]. It has been shown that $\mathrm{NH}_{4} \mathrm{Cl}-\mathrm{P}$ can be effectively intercepted and adsorbed by the large plant roots in the riparian zone, such that the migration of the $\mathrm{NH}_{4} \mathrm{Cl}-\mathrm{P}$ content into the river sediment is suppressed. This mechanism can even be leveraged as a coastal ecological interception method that can be applied during blue-green algae outbreaks in rivers or lakes [28].

In particular, the ratios of $\mathrm{NH}_{4} \mathrm{Cl}-\mathrm{P}$ to total phosphorus are $2.66 \%, 1.98 \%, 1.66 \%$, and $2.55 \%$ in the riparian soils from Chongyangxi, Nanpuxi, Songxi, and Jianxi catchments, respectively. The corresponding ratios in the sediments are $0.53 \%, 0.51 \%, 0.46 \%$, and $0.59 \%$, respectively. $\mathrm{NH}_{4} \mathrm{Cl}-\mathrm{P}$ was readily released from sediments and therefore was an estimate of the immediately available phosphorus [39]. A comparison of several river sections shows that the $\mathrm{NH}_{4} \mathrm{Cl}-\mathrm{P}$ ratio in the soils and sediments in the Songxi section ranks the lowest, indicating that the Songxi catchment has the least phosphorus available. This difference is most likely a consequence of the different land use in the river sections. The largest forest land area leads to more coarse particles and lower $\mathrm{NH}_{4} \mathrm{Cl}-\mathrm{P}$ content and less conducive $\mathrm{NH}_{4} \mathrm{Cl}-\mathrm{P}$ adsorption of the soil and sediment from the Songxi section.

\section{Distribution Characteristics of Redox-Sensitive Phosphorus (BD-P)}

BD-P represents the redox-sensitive $\mathrm{P}$ fraction, mainly including $\mathrm{P}$ bound to Fe hydroxides and Mn compounds [40]. It is generally considered as a potentially mobile P fraction and may be released from anaerobic sediments [38].

The soil types in the investigated area are widely distributed in sandy rock and granite, and the contents of $\mathrm{Fe}$ and $\mathrm{Mn}$ in sandstone and siltstone are high [13], which lead to a relatively high proportion of BD-P content in the riparian soils in this investigated area. BD-P in river 
sediments is released into overlying water under anoxic conditions and becomes internal phosphorus sources [38]. Therefore, this is the main reason that the ratio of BD-P content to IP content in sediments is lower than that in riparian soils in this investigated area.

The ratios of BD-P to IP are $21.39 \%, 21.61 \%, 20.63 \%$, and $22.79 \%$ in the riparian soils from Chongyangxi, Nanpuxi, Songxi, and Jianxi, respectively. The corresponding ratios in river sediments are $10.55 \%$, $9.89 \%, 11.62 \%$, and $10.77 \%$, respectively.

The comparison of several river sections shows that the BD-P ratio in riparian soils in the Songxi section is the lowest, but the corresponding ratio in river sediments is the highest. In environments with low oxygen concentrations, there is an increase of $\mathrm{P}$ release due to iron reduction, and the surfaces of oxy-hydroxides are modified [7]. In this condition the $\mathrm{Fe}(\mathrm{III}) \mathrm{Mn}$ (IV) (hydro) oxides would be reduced to $\mathrm{Fe}(\mathrm{II}) / \mathrm{Mn}$ (II) compound and result in enhanced dissolution of phosphorus at the water-sediment interface [2]. Therefore, it is likely due to the fact that water there contains more oxygenated because of less domestic discharge of urban activity, which is not conducive to the release of BD-P from the sediment into the overlying water, leading to a higher biological stability in the Songxi catchment.

\section{Distribution Characteristics of Metal Oxide-Bound Phosphorus (NaOH-P)}

The NaOH-P fraction is indicative of phosphorus bound to $\mathrm{Fe}$ and $\mathrm{Al}$ oxides $[38,40]$. Others have reported that the bio-available $\mathrm{P}$ extracted from TP mainly correlates with $\mathrm{NaOH}-\mathrm{P}$ in heavily polluted sediments [41]. Therefore, NaOH-P has been used to estimate both short- and long-term availability of $\mathrm{P}$, which is released for the growth of phytoplankton when anoxic conditions prevail at the water-sediment interface $[9,42]$.

The average ratio of $\mathrm{NaOH}-\mathrm{P}$ to IP is lower than $45 \%$ in riparian soils, and reaches more than $53 \%$ in the river sediments. This is likely caused by the fact that, compared to the riparian soil, the river water body can accept more point-source emissions. For example, in a process where domestic sewage and industrial wastewater is directly discharged into the river from ditches without going through the riparian soil, those pollution point sources may generate substances rich in aluminum and iron, which are in turn combined with phosphorus, forming $\mathrm{NaOH}-\mathrm{P}$ in the sediment. Therefore, the ratio of $\mathrm{NaOH}-\mathrm{P}$ to IP in river sediments is higher in various reaches of the investigated area compared to that in riparian soils.

In addition, compared to the malodorous and eutrophicated river sediment that has lower dissolved oxygen (DO) concentrations, more DO in Jianxi Basin, whose water quality is in an oligotrophic to mesotrophic state, will stimulate the transformation of $\mathrm{Fe}^{2+}$ into $\mathrm{Fe}^{3+}$, and $\mathrm{Fe}^{3+}$ can bind with phosphate to form $\mathrm{Fe}_{2}\left(\mathrm{PO}_{4}\right)_{3}$, precipitating to the sediments [13, 42]. Moreover, dissolved $\mathrm{P}$ in the overlying water can be absorbed by oxides and hydroxides of $\mathrm{Fe}$ and $\mathrm{Al}$ in the sediments to further form $\mathrm{Fe}(\mathrm{OH})-\mathrm{P}$ or $\mathrm{Al}(\mathrm{OH})-\mathrm{P}$ complexes that are classified into NaOH-P [43].

Specifically, the average ratios of NaOH-P to IP in riparian soils are $44.98 \%, 44.46 \%, 39.33 \%$, and $43.25 \%$ in the Chongyangxi, Nanpuxi, Songxi, and Jianxi, respectively. The corresponding ratios in river sediments are $62.71 \%, 63.20 \%, 52.88 \%$, and $59.84 \%$, respectively. A comparison concerning various river sections indicates that the ratio of $\mathrm{NaOH}-\mathrm{P}$, as one of the main forms of bioavailable phosphorus, is lowest in Songxi reach, showing that the ratio of bioavailable phosphorus in the Songxi section is lower and the phosphorus fraction is relatively stable. Abdala et al. reported that increased $\mathrm{Fe}$ and $\mathrm{Al}$ oxyhydroxides and hydroxides in soils caused by longterm manure application increased the ability of the soil to sorb $\mathrm{P}$ [44]. Therefore, there is more $\mathrm{NaOH}-\mathrm{P}$ content in the soil plus sediment from Chongyangxi and Nanpuxi catchment with more anthropic intervention.

\section{Distribution Characteristics of Carbonate-Bound Phosphorus (HCl-P)}

$\mathrm{HCl}-\mathrm{P}$ refers to the $\mathrm{P}$ fraction sensitive to low $\mathrm{pH}$. It consists of the apatite $\mathrm{P}$ (natural and detritus $\mathrm{P}$ ), the carbonate-bound $\mathrm{P}$, and some hydrolysable organic $\mathrm{P}$ [28]. This $\mathrm{P}$ fraction is considered to be the most stable form of inorganic phosphorus and is generally not bio-available [45]. It can be treated as a permanent phosphorus sink, making little contribution to eutrophication under normal conditions.

Specifically, the average ratios of HCl-P to IP in riparian soils are $30.97 \%, 31.95 \%, 38.38 \%$, and $31.41 \%$ in the Chongyangxi, Nanpuxi, Songxi, and Jianxi, respectively. The corresponding ratios in river sediments are $26.21 \%, 26.40 \%, 35.04 \%$, and $28.79 \%$, respectively. A comparison concerning several river sections indicates that the ratio of HCl-P in soils and river sediments in Songxi shore is highest. This is due to the small population of the catchment, high forest coverage, large plants intercepting fine particles, and the fact that the riparian soils and river sediments mainly consist of coarse debris particles. A previous study shows that coarse particles are one of the sources of HCl-P, and the coarse particles are easy to deposit, leading to a positive correlation between particle size and HCl-P content [3]. Furthermore, high $\mathrm{pH}$ and $\mathrm{Ca}^{2+}$ concentration in the water column could reduce the phosphorus adsorption by $\mathrm{Fe}(\mathrm{OOH})$ particles, and $\mathrm{Ca}^{2+}$ in turn would tend to form $\mathrm{Ca}_{5}(\mathrm{PO} 4)_{3} \mathrm{OH}$ precipitate with orthophosphate [37]. Therefore, HCl-P in Songxi catchment increases obviously. Over the course of a short time, the damage of HCl-P to the environment is very small. The increasing inputs of external $\mathrm{P}$ in recent decades and the mineralization of organic phosphorus or the other $\mathrm{P}$ fractions could accelerate the formation of calcium-bound phosphorus. In the long run or in the case where the water environment changes (e.g., the intensification of microbial activity), HCl-P may be released from sediments into the overlying water and lead to water pollution $[2,13]$. 


\section{Distribution Characteristics of Bio-Available Phosphorus (BAP)}

Bio-available phosphorus (BAP) is defined as the sum of $\mathrm{NH}_{4} \mathrm{Cl}-\mathrm{P}, \mathrm{BD}-\mathrm{P}$, and $\mathrm{NaOH}-\mathrm{P}$, and this value can be used to estimate the potential available $\mathrm{P}$ for plants or algae $[8,46]$. It can be easily desorbed form sediments and released into the overlying water when environmental conditions change, and has a close relationship with water quality and the type of water ecosystem [37].

From the comparison of phosphorus contents in different sections, the order of the BAP contents in the four river banks is: Songxi $(268.91 \mathrm{mg} / \mathrm{kg})>$ Jianxi $(229.30$ $\mathrm{mg} / \mathrm{kg})>$ Nanpuxi $(223.53 \mathrm{mg} / \mathrm{kg})>$ Chongyangxi $(162.88 \mathrm{mg} / \mathrm{kg})$. The corresponding order associated with the sediments is: Nanpuxi $(307.61 \mathrm{mg} / \mathrm{kg})>$ Jianxi $(279.43 \mathrm{mg} / \mathrm{kg})>$ Chongyangxi $(240.00 \mathrm{mg} / \mathrm{kg})>$ Songxi $(231.72 \mathrm{mg} / \mathrm{kg})$.

From the comparison of the ratios of phosphorus forms in different river sections, the ratios of BAP to IP in four riparian soils follow the order: Chongyangxi $(69.03 \%)>$ Jianxi $(68.60 \%)>$ Nanpuxi $(68.05 \%)>$ Songxi $(61.62 \%)$. In the case of sediments, we have: Chongyangxi (73.78\%) $>\operatorname{Nanpuxi}(73.59 \%)>\operatorname{Jianxi}(71.21 \%)>$ Songxi $(64.96 \%)$.

It can be seen that the BAP content in the soils and sediments is lowest at the Chongyangxi section with the highest tea garden coverage and the most developed tourism industry, where the ratio of BAP to IP peaks. It reflects that the tourism management activities curtail phosphorus emissions to certain extent, but tea plants lead to soil acidification [47], and the intensified human activities caused by tourism stimulate phosphorus activity in the Chongyangxi catchment. In contrast, the BAP content in riparian soils of the Songxi section is highest, but the BAP content in the river sediments is lowest, and the ratio of BAP to IP is also lowest. A previous study showed that forested wetlands had higher organic content than emergent marsh systems, which was also correlated with higher phosphorus sorption [12]. A previous study reported on city suburbs with high urban populations and relative low nutrient surplus, and those located at the vicinity of cities or city suburbs with low urbanization and high nutrient surplus in topsoil from China's Fujian province [22]. Our study result show that low population density and high forest land coverage further intercept a lot of terrestrial BAP content, and also reduce the phosphorus activity of Songxi catchment, which largely protects water quality. It can be seen that water ecological environment evaluation should not only consider phosphorus content, but also needs to account for the phosphorus forms.

\section{Environmental Significance of Phosphorus Distribution in Riparian Soils and River Sediments}

\section{Correlation Analysis of Phosphorus in Riparian Soils and River Sediments}

There is a correlation among elements from the same source that can be leveraged to tell whether the elements are from the same source [3]. The Pearson correlation coefficient matrix of phosphorus forms in riparian soils and river sediments is shown in Table 2, which shows that the TP contents, and BD-P, NaOH-P, and HCl-P contents in riparian soils are significantly positively correlated $(r=0.750, r=0.701, r=0.924 ; p<0.01)$, suggesting that the TP and three main phosphorus forms may be derived from the same source of pollution. Previous studies show that external origin comes from diffuse sources (natural, agricultural) or point sources (industrial and domestic effluents), which are the main pollution sources of TP and phosphorus forms such as BD-P, NaOH-P, and HCl-P in soil [9]. The investigation of the environment surrounding the sampling point indicates that the sampling points with serious phosphorus pollution are mainly located where intense human activities take place, such as the discharge of domestic sewage, the storage of garbage, and the application of pesticides and fertilizers. Therefore, it can be inferred that the TP and main phosphorus forms such as BD-P, NaOH-P and HCl-P are mainly affected by residential and agricultural activities. TP in river sediments is positively correlated with $\mathrm{NaOH}-\mathrm{P}$ and HCl-P $(\mathrm{R}=0.825, \mathrm{R}=0.746 ; \mathrm{P}<0.01)$, as $\mathrm{NaOH}-\mathrm{P}$ and HCl-P are the main forms of phosphorus in TP. The spatial distribution characteristics of phosphorus forms in sediments also show that TP follows a similar trend with $\mathrm{NaOH}-\mathrm{P}$ content and HCl-P content, which is consistent with the results of correlation analysis.

Table 2. Pearson's correlation coefficients of $\mathrm{P}$ fractions in riparian soils and river sediments.

\begin{tabular}{|c|c|c|c|c|c|c|c|c|c|c|}
\hline \multicolumn{9}{|c|}{ Soil } & \multicolumn{5}{c|}{ Sediment } \\
\hline Item & TP & NH ${ }_{4}$ Cl-P & BD-P & NaOH-P & HCl-P & TP & NH $_{4}$ Cl-P & BD-P & NaOH-P & HCl-P \\
\hline $\mathrm{TP}$ & 1.000 & & & & & 1.000 & & & & \\
\hline $\mathrm{NH}_{4} \mathrm{Cl}-\mathrm{P}$ & 0.271 & 1.000 & & & & 0.069 & 1.000 & & & \\
\hline $\mathrm{BD}-\mathrm{P}$ & $0.750^{* *}$ & 0.273 & 1.000 & & & 0.253 & -0.045 & 1.000 & & \\
\hline $\mathrm{NaOH}-\mathrm{P}$ & $0.701^{* *}$ & 0.366 & $0.698^{* *}$ & 1.000 & & $0.825^{* *}$ & 0.109 & 0.162 & 1.000 & \\
\hline $\mathrm{HCl}-\mathrm{P}$ & $0.924^{* *}$ & 0.352 & $0.713^{* *}$ & $0.767^{* *}$ & 1.000 & $0.746^{* *}$ & 0.011 & 0.170 & $0.563^{* *}$ & 1.000 \\
\hline
\end{tabular}

*Correlation is significant at the 0.05 level, $\mathrm{n}=23$ (two-tailed)

$* *$ Correlation is significant at the 0.01 level, $\mathrm{n}=23$ (two-tailed) 
Table 3. Pearson's correlation coefficients of $\mathrm{P}$ fractions in river sediments and the counterparts in riparian soils.

\begin{tabular}{|c|c|c|c|c|c|}
\hline Item & $\mathrm{TP}_{\text {sediment }}$ & $\mathrm{NH}_{4} \mathrm{Cl}-\mathrm{P}_{\text {sediment }}$ & $\mathrm{BD}-\mathrm{P}_{\text {sediment }}$ & $\mathrm{NaOH}-\mathrm{P}_{\text {sediment }}$ & $\mathrm{HCl}_{\text {sediment }}$ \\
\hline $\mathrm{TP}_{\text {soil }}$ & $0.561^{* *}$ & & & & \\
\hline $\mathrm{NH}_{4} \mathrm{Cl}_{\mathrm{P}} \mathrm{P}_{\text {soil }}$ & & -0.176 & & & \\
\hline $\mathrm{BD}-\mathrm{P}_{\text {soil }}$ & & & $0.422^{*}$ & & \\
\hline $\mathrm{NaOH}-\mathrm{P}_{\text {soil }}$ & & & & 0.234 & $0.522^{*}$ \\
\hline $\mathrm{HCl}_{\text {soil }}$ & & & & & \\
\hline
\end{tabular}

*Correlation is significant at the 0.05 level, $\mathrm{n}=23$ (two-tailed)

$* *$ Correlation is significant at the 0.01 level, $\mathrm{n}=23$ (two-tailed)

Correlation analysis of TP and various forms of phosphorus content in river sediments with the corresponding elements in riparian soils is presented in Table 3. It shows that TP, BD-P, and HCl-P contents in river sediments and in the riparian soils are significantly positively correlated $(\mathrm{r}=0.561, \mathrm{p}<0.01 ; \mathrm{r}=0.422$, $\mathrm{r}=0.522, \mathrm{p}<0.05$ ), indicating that TP, BD-P, and HCl-P in the river sediments and in riparian soils are more or less from the same source. The riparian zone, as the transition zone between the water and the land ecological system, has a special geographical location, and many factors can lead to the accumulation of $\mathrm{P}$ in riparian zone soil, such as domestic sewage, industrial wastewater discharge, human recreation, and garbage storage. Subsequently, the accumulated $\mathrm{P}$ will be continuously transported into the rivers by the surface runoff, which becomes the main phosphorus pollution source for river sediments [17]. In addition, river sediments also cause soil phosphorus pollution as driven by the seasonal fluctuation of the river water level [40].

\section{Influence of Watershed Environment on Phosphorus Distribution in Riparian Soils and River Sediments}

The above results showed that the distributions of phosphorus forms in riparian soils and river sediments had internal relationships. Meanwhile, anthropogenic activities disturb the distribution of TP and phosphorus fractions in riparian soils and river sediments. Average $\mathrm{NaOH}-\mathrm{P}$ content is higher in river sediments than in riparian soils because the former can accept more pointsource emissions (e.g., domestic sewage and cultural wastewater), and which is not positively correlated with $\mathrm{NaOH}-\mathrm{P}$ in riparian soils. Compared to river sediments, phosphorus distribution of the riparian soil is easily influenced by the geological environment, and phosphorus forms are associated with local soil properties. The spatial distributions of phosphorus forms in river sediments are relatively homogeneous but show the variation in different catchment reaches.

On the whole, NaOH-P and HCl-P are the main IP forms, and NaOH-P > HCl-P in the soils and river sediments of watershed. This is correlated with the acidic soil because Jianxi Basin is located in a granite area of southeastern China [20]. Compared to other catchments, the highest phosphorus and BAP concentrations are in riparian soil from Songxi catchment with the lowest urbanization. But the BAP content in river sediments seems to be lowest, because the soil in Songxi catchment is covered by the largest woodland area, which hinders terrigenous phosphorus into the river [9]. In contrast, the lower total phosphorus and BAP content is observed in sediments of Chongyangxi catchment with the highest urbanization and most tea garden area, and the ratio of $\mathrm{BAP} / \mathrm{IP}$ in soil and sediment is largest. This indicates that intense human activities can increase the phosphorus biological availability. Although forest coverage rate (near 75\%) is high in the whole basin [20], urbanization has destroyed the nutritional balance of the soil [22], and began to accumulate nutrient elements in river sediments. To some extent, the increasing nutrients of the Jianxi will destroy water quality in the downstream reaches of the Minjiang. Therefore, more attention should be paid to the basin management of land use and pollution discharge, and water quality should be of sufficient concern.

\section{Conclusions}

1. The contents of $\mathrm{OM}, \mathrm{TN}$, and $\mathrm{TP}$ in the riparian soils are higher than those in the sediments in Jianxi Basin, whose water quality is in an oligotrophic to mesotrophic state. The contents of $\mathrm{NH}_{4} \mathrm{Cl}-\mathrm{P}, \mathrm{BD}-\mathrm{P}$, and $\mathrm{HCl}-\mathrm{P}$ in riparian soils are higher than those in sediments.

2. The average phosphorus forms in riparian soils and sediments follow the order: $\mathrm{NaOH}-\mathrm{P}>\mathrm{HCl}-\mathrm{P}>\mathrm{BD}-\mathrm{P}$ $>\mathrm{NHCl}_{4}$-P. This is correlated with the acidic soil of the granite area in Jianxi Basin. But the distributions of phosphorus forms are not completely consistent between river sediments and riparian soils in the whole watershed.

3. Compared to total phosphorus, bioavailable phosphorus is readily affected by the catchment geological background and land use, which shows significant variations at different catchments.

4. Anthropogenic activities change the distributions of phosphorus forms (BD-P, NaOH-P, and $\mathrm{HCl}-\mathrm{P}$ ) in riparian soils, and further affect their distributions in river sediments. Due to urbanization, nutrient 
elements begin to accumulate in river sediments, and the water quality management in Jianxi Basin should be concerned sufficiently.

\section{Acknowledgements}

This research was supported by the National Natural Science Foundation of China (41372354), the publicbenefit project of the Ministry of Land and Resource of China (201111021), and the Priority Academic Program Development of Jiangsu Higher Education Institutions (PPZY2015A051). The authors would like to thank Haiyan Xu and Zhengyang Li for their field work support. We are grateful to Jing Jin for laboratory work.

\section{References}

1. CONDRON L.M., NEWMAN S. Revisiting the fundamentals of phosphorus fractionation of sediments and soils. Journal of Soils and Sediments. 11 (5), 830, 2011.

2. WANG C.H., HE R., WU Y., LURLING M., CAI H.Y., JIANG H.L., LIU X. Bioavailable phosphorus (P) reduction is less than mobile $\mathrm{P}$ immobilization in lake sediment for eutrophication control by inactivating agents. Water Research. 109, 196, 2017.

3. HU J., LIU J.T., LIU Y.D. Phosphorus in suspended matter and sediments of a hypertrophic lake. A case study: Lake Dianchi, China. Environmental Geology. 58 (4), 833, 2009.

4. ZHU Y.R., ZHANG R.Y., WU F.C., QU X.X., XIE F.Z, FU Z.Y. Phosphorus fractions and bioavailability in relation to particle size characteristics in sediments from Lake Hongfeng, Southwest China. Environmental Earth Sciences. 68 (4), 1041, 2013.

5. ZHANG H.Y., TIAN Y.L., CUI S.B., ZHANG L.Y., ZHONG $\mathrm{X}$., XIONG Y.W. Influence of macrophytes on phosphorus fractionation in surface sediments in a constructed wetland: Insight from sediment compositions. Ecological Engineering. 97, 400, 2016.

6. VICENTE M.A.F., MELO G.V., NETO J.A.B., OLIVEIRA A.S. Phosphorus fractionation distribution in Guapimirim estuary: SE Brazil. SpringerPlus. 5 (1), 1406, 2016.

7. DOIG L.E., NORTH R.L., HUDSON J.J., HEWLETT C., LINDENSCHMIDT K.E., LIBER K. Phosphorus release from sediments in a river-valley reservoir in the northern Great Plains of North America. Hydrobiologia. 787(1), 323, 2017.

8. HAN L., HUANG S.L., STANLEY C.D., OSBORNE T.Z. Phosphorus Fractionation in Core Sediments from Haihe River Mainstream, China. Soil and Sediment Contamination. 20 (1), 30, 2011.

9. ZHOU Q.X., GIBSON C.E., ZHU Y.M. Evaluation of phosphorus bioavailability in sediments of three contrasting lakes in China and the UK. Chemosphere. 42 (2), 221, 2001.

10. YANG Q.Z., ZHAO H.Z., ZHAO N.N., NI J.R., GU X.J. Enhanced phosphorus flux from overlying water to sediment in a bioelectrochemical system. Bioresource technology. 216, $182,2016$.

11. ZHANG M., CHEN F.Q., CHEN S.H., WANG Y.J., WANG J.Z. Effects of the seasonal flooding on riparian soil seed bank in the Three Gorges Reservoir Region: a case study in Shanmu River. SpringerPlus. 5 (1), 492, 2016.
12. LANE C.R., AUTREY B.C. Phosphorus retention of forested and emergent marsh depressional wetlands in differing land uses in Florida, USA. Wetlands Ecology and Management. 24 (1), 45, 2016.

13. CHEN H.L., YUAN X.Y., WANG H., LI Z.Y., XU H.Y. Distribution of phosphorus fraction in suspended sediments and surface sediments of Tiaoxi mainstreams and cause analysis. Environmental Science. 36 (2), 464, 2015 [In Chinese].

14. YOUNG E.O., ROSS D.S. Total and labile phosphorus concentrations as influenced by riparian buffer soil properties. Journal of environmental quality. 45 (1), 294 , 2016.

15. KIM L.H., CHOI E., GIL K.I., STENSTROM M.K. Phosphorus release rates from sediments and pollutant characteristics in Han River, Seoul, Korea. Science of the Total Environment. 321 (1), 115, 2004.

16. BIBBY R.L., WEBSTER-BROWN J.G. Characterisation of urban catchment suspended particulate matter (Auckland region, New Zealand); a comparison with non-urban SPM. Science of the Total Environment. 343 (1), 177, 2005.

17. KERR J.G., BURFORD M.A., OLLEY J.M., BUNN S.E., UDY J. Examining the link between terrestrial and aquatic phosphorus speciation in a subtropical catchment: The role of selective erosion and transport of fine sediments during storm events. Water Research. 45 (11), 3331, 2011.

18. HONGTHANAT N., KOVAR J.L., THOMPSON M.L., RUSSELL J.R., ISENHART, T.M. Phosphorus source - sink relationships of stream sediments in the Rathbun Lake Watershed in southern Iowa, USA. Environmental monitoring and assessment. 188 (8), 1, 2016.

19. CHEN Y., CHEN X.W., YIN Y.X. Characteristics of Runoff Changes in the Minjiang River Basin from 1960 to 2006. Journal of natural resources. 26 (8), 1401, 2011 [In Chinese].

20. QUAN B., ZHU H.J., CHEN S.L., ROMKENS M.J.M., LI B.C. Land Suitability Assessment and Land Use Change in Fujian Province, China. Pedosphere. 17 (4), 493, 2007.

21. YE H.M., LI G.P., YUAN X.Y., WU F.F., ZENG R.N., LIU Y.B. Hydro-chemical characteristics and source contribution for small mountainous basin: A case study in the Jiuquxi basin, Wuyishan. Environmental Chemistry. 35 (3), 581, 2016 [In Chinese].

22. CAO W.Z., ZHU H.J., Chen S.L. Impacts of urbanization on topsoil nutrient balances - a case study at a provincial scale from Fujian, China. Catena. 69 (1), 36, 2007.

23. Institute of Soil Science, Chinese Academy of Sciences. Physico-chemistry analysis of soil. Shanghai: Shanghai Science and Technology Publishing Company. 1978.

24. TIAN H.Q., CHEN G.S., ZHANG C., MELILLO J.M., HALL C.A.S. Pattern and variation of C: N: P ratios in China's soils: a synthesis of observational data. Biogeochemistry. 98 (1-3), 139, 2010.

25. KIM H.T. Soil sampling, preparation and analysis. Marcel Dekker, New York. 1995.

26. HAN L., HUANG S.L., STANLEY C.D., OSBORNE T.Z. Phosphorus fractionation in core sediments from Haihe River Mainstream, China. Soil and Sediment Contamination. 20 (1), 30, 2011.

27. HUPFER M., GACHTER R., GIOVANOLI R. Transformation of phosphorus species in settling seston and during early sediment diagenesis. Aquatic Sciences. 57 (4), 305, 1995.

28. WANG S.R., JIN X.C., ZHAO H.C., WU F.C. Phosphorus fractions and its release in the sediments from the shallow lakes in the middle and lower reaches of Yangtze River area 
in China. Colloids and Surfaces A: Physicochemical and Engineering Aspects, 273 (1), 109, 2006.

29. MURPHY J., PILEY J.P. A modified single solution method for the determination of phosphate in natural waters. Analytica Chimica Acta. 27, 31, 1962.

30. KATSAOUNOS C.Z., GIOKAS D.L., LEONARDOS I.D., KARAYANNIS M.I. Speciation of phosphorus fractionation in river sediments by explanatory data analysis. Water Research. 41 (2), 406, 2007.

31. HOFFMANN C.C., KJAERGAARD C., UUSI-KAMPPA J., HANSEN H.C.B., KRONVANG B. Phosphorus retention in riparian buffers: review of their efficiency. Journal of Environmental Quality. 38 (5), 1942, 2009.

32. MANKIN K.R., NGANDU D.M., BARDEN C.J., HUTCHINSON S.L., GEYER W.A. Grass - shrub riparian buffer removal of sediment, phosphorus, and nitrogen from simulated runoff. JAWRA Journal of the American Water Resources Association. 43 (5), 1108, 2007.

33. MAGUIRE R.O., SIMS J.T. Soil testing to predict phosphorus leaching. Journal of Environmental Quality. 31 (5), 1601, 2002.

34. ZHOU A.M., TANG H.X., WANG D.S. Phosphorus adsorption on natural sediments; Modeling and effects of $\mathrm{pH}$ and sediment composition. Water Research. 39 (7), 1245, 2005.

35. SU J.J., VAN BOCHOVE E., AUCLAIR J.C., THERIAULT G., DENAULT J.T., BOSSE C., LI X.Y., HU C.X. Phosphorus algal availability and release potential in suspended and streambed sediments in relation to sediment and catchment characteristics. Agriculture, Ecosystems \& Environment. 188, 169, 2014

36. ERIKSSON A.K., GUSTAFSSON J.P., HESTERBERG D. Phosphorus speciation of clay fractions from long-term fertility experiments in Sweden. Geoderma. 241, 68, 2015.

37. HOU D.K., HE J., LU C.W, DONG S.W., WANG J.H., XIE Z.L., ZHANG F.J. Spatial variations and distributions of phosphorus and nitrogen in bottom sediments from a typical north-temperate lake, China. Environmental Earth Sciences. 71 (7), 3063, 2014.
38. KAISERLI A., VOUTSA D., SAMARA C. Phosphorus fractionation in lake sediments - Lakes Volvi and Koronia, N. Greece. Chemosphere. 46 (8), 1147, 2002.

39. RYDIN E. Potentially mobile phosphorus in Lake Erken sediment. Water Research. 34 (7), 2037, 2000.

40. KOZERSKI H.P., KLEEBERG A. The sediments and benthic-pelagic exchange in the shallow Lake Müggelsee (Berlin, Germany). International Review of Hydrobiology. 83(1), 77, 1998.

41. WANG S.R., JIN X.C., BU Q.Y., LIAO H.Q., WU F.C. Evaluation of phosphorus bioavailability in sediments of the shallow lakes in the middle and lower reaches of the Yangtze River region, China. Environmental Earth Sciences. 60 (7), 1491, 2010.

42. ZHU J., HE Y., WANG J.H., QIAO Z.C., WANG Y., LI Z.H., HUANG M.S. Impact of aeration disturbances on endogenous phosphorus fractions and their algae growth potential from malodorous river sediment. Environmental Science and Pollution Research. 1, 2017.

43. JIN X.D., HE Y.L., KIRUMBA G., HASSAN Y., LI J.B. Phosphorus fractions and phosphate sorption-release characteristics of the sediment in the Yangtze River estuary reservoir. Ecological Engineering. 55, 62, 2013.

44. ABDALA D.B., DA SILVA I.R., VERGUTA L., SPARKS D.L. Long-term manure application effects on phosphorus speciation, kinetics and distribution in highly weathered agricultural soils. Chemosphere. 119, 504, 2015.

45. GONSIORCZYK T., CASPER P., KOSCHEL R. Phosphorus-binding forms in the sediment of an oligotrophic and an eutrophic hardwater lake of the Baltic Lake District (Germany). Water Science and Technology. 37 (3), 51, 1998.

46. LIU Q., LIU S.L., ZHAO H.D., DENG L., WANG C., ZHAO Q.H., DONG S.K. The phosphorus speciations in the sediments up-and down-stream of cascade dams along the middle Lancang River. Chemosphere. 120, 653, 2015.

47. LI S.Y., LI H.X., YANG C.L., WANG Y.D., XUE H., NIU Y.F. Rates of soil acidification in tea plantations and possible causes. Agriculture, Ecosystems \& Environment. 233, 60, 2016. 